\title{
The Development of Android Application Familiarization to Variety of Profession Based on Applied Science Cluster
}

\author{
Khilda Wulidatin Noor ${ }^{1, a}$, Dede Rahmat Hidayat ${ }^{1, b}$, Wirda Hanim ${ }^{1, c}$ \\ ${ }^{1}$ Magister of Guidance and Counseling, Universitas Negeri Jakarta, Indonesia \\ a khildawulidatin@mahasiswa.unj.ac.id; b dederhidayat@unj.ac.id; c hanim12@unj.ac.id \\ ${ }^{*}$ Corresponding Author \\ Whatsapp number: [082220664587]
}

How to Cite : Noor, K., W., Hidayat, D., R., Hanim, W. (2019). The Development of Android Application Familiarization to variety of Profession Based on Applied Science Cluster. International Journal for Educational and Vocational Studies, 1 (6), 560-563

\section{ARTICLE HISTORY}

Received: 3 July 2019

Revised: 28 August 2019

Accepted: 12 September 2019

\section{KEYWORDS}

Professional Variety;

Android Applications;

Elementary School Students;

\begin{abstract}
The purpose of this study is to develop a familiarization to the variety of professions that can be familiarized by classifying professions based on applied science clusters in Indonesia in accordance with the Constitution of the Republic of Indonesia Number 12 of 2012 concerning Higher Education in article 10 section 2 which reads: "... (a) religion knowledge; (b) humanities; (c) social science clusters; (d) natural sciences; (e) formal science clusters; and (f) applied science, with android applications. Variety of professions is an activity carried out by someone to support themselves and their families where the profession is governed by professional ethics where the ethics of the profession applies only to those professions. Besides the familiarization of various professions since elementary school age is a strategic choice in preparing future generations, the variety of professions is needed by students from the age of elementary school, as a reference for their ideals. Following the times, the familiarization of various professions can be applied in technology. The method used is research and development, which develops Android applications, based on the applied science clusters. It is expected that students can get to know and choose a picture related to their future career.
\end{abstract}

This is an open access article under the CC-BY-SA license.

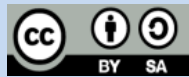

\section{INTRODUCTION}

Elementary school learners begin to restrict their decision about their career based on the information that they acquire from their environment (Brown, 2002). Information about career becomes very essential to be understood by elementary school learners. In fact, it shown that the reform of career is such a huge challenge for a country with a low income per capita and for a developing country (Oecd, 2005). References and studies about learners' career development in Indonesia in terms of quantities and varieties which have not been adequate. References are very crucial especially in the development of vocation is hard to find rather than adolescent and adults (Hartung, 2005). iterally, guidance for future career should be given to elementary school children even kindergarten children with assumption that career development influence long term process; comprehensive career programs tailored to age, and include experiential activities (Zunker, 2006).
Ideals of career for elementary school learners is not an ease to determined and become a choice that suitable with their ability since there are many children do not recognize that ideals are the right ways to in the effort to have a perfect future. By having an ideal, someone would have a motivation to make it come true. Introduction to a variety of professions is a need for elementary school learners as a reference for their ideals. It is in order to guide the learners recognize and determine a concept for their future. Moreover, familiarization of career variety since elementary school years is a great decision to prepare the generations in the future (Salahudin, 2010). Familiarization of various career to elementary school children is not adequate yet, according to the observations that have been conducted showed that the low frequency of counselling is considered to be the reason why the provision of guidance as one of the familiarization of various professions is difficult to implement (Azhari, 2016). 
Figuring out that the use of games in learning can improve learners' proficiency positively, learners become active and enthusiastic hence it raises the substance in learning (Beck, 2016), improve learners' understanding of a community through teamwork (Rossiter, 1998). The implementation of innovation in teaching and learning activity is crucial in intention to the improvement of education.

The studies showed that the familiarization of various career have to be familiarized as soon as possible since how important it is in terms of human career, hence, children are prepared in the early stage and adults have a responsibility in helping them to plan their future by educating and guiding them continuously in terms of career. In addition, they like role play (e.g. role play as doctors and their patient, as a teacher, police, etc.) as what they see in their environment. The professions or jobs that they play are still influenced by their environment, such as from TV, internet, magazines, movies, even the persons they have ever known in their life.

Children at the age from 10 to 12 are considered in a growth stage in career. This stage has four sub-stages of growth; those are stage of developing curiosity, fantasies, interest, and capacities (Super, 1990). Consider the importance of familiarization of career development for elementary school learners, it is expected that familiarization of career development will be given immediately in school. Literally, familiarization of career development is a process that intended to introduce a variety of profession and career to children.

For a long time, in giving a guidance and counseling, schools tend do in a monotonous way, teachers still tend to lecturing the students, they do not have any attractive method and media to do the right way. In order to overcome such kinds of problems, many researchers created innovative of media, for instance, developing module, posters, and pocket books. However, this kind of innovations has already widely utilized these past few years. Besides innovations of media, there are also innovative methods, such as role play, cluster discussion, and games.

Games are very rarely used in schools even though these methods can attract and increase student enthusiasm in attending guidance and counseling services. As expressed "Aspects of children's development can grow optimally and optimally through play activities" (Adriana, 2011). Innovative and creative methods that have high quality benefits are considered necessary to be used in counseling guidance services, one of them is the game method.

Familiarization of career development can be familiarized by classifying the professions based on the cluster of applied science in Indonesia in accordance with Constitution of the Republic of Indonesia Number 12 in 2012 concerning Higher Education in article 10 section 2 that state: “... (a) cluster of religion science; (b) cluster of humanities science; (c) social science cluster; (d) natural science cluster; (e) formal science cluster; and (f) the cluster of applied science (UUD, 2012).

Absolutely, it helps the school counselors to deliver the information easier related to a variety of professions. In this study, the use of applications on android, the familiarization to variety of profession as reference to learners' ideals in higher level can be used to help learners enhance their reference.

\section{LITERATURE REVIEW}

\subsection{Elementary Learners' Career Development}

Sunaryo Kartadinarta and Nani Sugandi (2002) state that the development of career is a part of human's development, because:

a. Development occurs all the human lifetime

b. Individual development is influenced by innative factor and environment

c. Development is a continuous process

d. Even though the development is continuous there are dominant aspects in various periods of development, the dominant aspects at a particular stage of development should be taken into account in the career development program.

e. Individual development includes the differentiation and integration of self-concepts and perceptions about their world, and

f. The individual development, hence it has a variety of individuals.

Ginzberg, Ginsberg, Axeirad dan Herma (Sunaryo, 2002) explain that the choice of position is not occurred once, but it has a developmental process that covers a period between 6 and 15 years. Fantasy period from birth to 11 years, during the fantasy phase of children, they are solely just playing around and it is considered that this game has no relation with the career.

Meanwhile, according to Super (1990), children aged 10-12 years are categorized in growth stage of career. This stage consist of four sub-stages; the stage of curiosity development, fantasies, interest, and capacities. However, those statements show that children aged 10-12 years are categorized in the sub-stages interest and capacities. It was indicated when children's interest comes in particular careers, for example the interest to be a professional chef, so he began to pursue and enjoy cooking. However, at this stage they have not considered the inhibiting factors of their desired career. Then the sub stages of developing capacity (capacities) are the basis for the formation of skills in certain careers. At this stage, it can be said as a stage where children will develop their abilities in achieving their goals, such as learning a foreign language, and skills that are in accordance with their dreams.

\subsection{Variety of Profession}

Variety of profession is a process that someone doing in intention to provide for their life and/or their family where the profession is governed by the ethics of profession that it is applied only in the same profession (Adriansyah, 2012). 
There are various types of professions that can be introduced to children, namely the variety of potentials professions in Indonesia. Familiarization of this variety of professions can be familiarized by classifying the professions based on the cluster of applied science in Indonesia in accordance with Constitution of the Republic of Indonesia Number 12 in 2012 concerning Higher Education in article 10 section 2 that state: “... (a) cluster of religion science; (b) cluster of humanities science; (c) social science cluster; (d) natural science cluster; (e) formal science cluster; and (f) the cluster of applied science (UUD, 2012).

\subsection{User Interface}

User interface is part of computer devices and software where people can see, listen, touch, and understand each other directly. There are the principals of interface design, those are (Rina, 2016):

\section{Aesthetics}

It uses the graphical principles, such as rhyme, repetition, gradation, stress, etc.

2. Clarify

It has clear visual, concept, and language.

3. Compatibility

It provides compatibility for users, orders, products, and adjusts the users' prespectives.

4. Comprehensive

It means an understandable and useable system.

5. Consistency

User interface should perform, work, and operate in a system consistently.

\section{METHODS}

The method used in this research is Research and Development. It was conducted through some stages. In this research, it still in the stage of design and concept then it will be followed bya stage where the development of application to make the familiarization variety of profession application. Next step, we conducted an initial trials and continued to mass trials.

This study was based on literature reviews obtained from journals, books and several other literatures. The data analysis was done from the literatures. In this stage, we looked for the correlation between each aspect and indicator. The aspects and indicators of the variety of professions that categorized in the cluster of knowledge are as follows:

Table 1. Elaboration of Republic of Indonesia Constitution Number 12 in 2012 concerning Higher Education

\begin{tabular}{ll}
\hline Cluster of Science & \multicolumn{1}{c}{ Description } \\
\hline Humanities & $\begin{array}{l}\text { Art observers, dancers, musicians, artists, historians, } \\
\text { writers, language teachers, translators and } \\
\text { philosophers. }\end{array}$ \\
\hline Social Science & $\begin{array}{l}\text { Anthropologists, archaeologists, economists, bank } \\
\text { employees, psychologists, earth experts, sociologists, } \\
\text { diplomats, politicians and political observers. }\end{array}$ \\
\hline Nature Science & Biologists, scientists, earth movement observers, \\
\hline
\end{tabular}

\begin{tabular}{ll}
\hline & physicists, astronauts, and astronomers. \\
\hline Formal Science & Statisticians, programmers, computer experts, \\
& mathematicians, lecturers, and technology observers. \\
\hline Applied Science & Farmers, breeders, architects, graphic designers, \\
& product designers, interior designers, accountants, \\
& managers, doctors, engineers, doctors, nutritionists, \\
& midwives, pharmacists, nurses, athletes, journalists, \\
& cameramen, lawyers, notaries, police, librarians, \\
& soldiers, pilots, flight attendants, engineers, mechanics \\
& and tour guides. \\
\hline
\end{tabular}

\section{RESULTS AND DISCUSSION}

Profession is a thing that someone doing to provide for themselves and their families where the profession is governed by Professional Ethics where the Professional Ethics applies only to the Profession. The familiarization of professional development as a reference for ideals is one way to help students provide direct experience, because what is contained in the game does not involve lecture material, or only reading, but also helps students think and cooperate, and have a series of activities.

As one of the guidance and counseling part in the career field, the familiarization of professional development will be given to students, it is carried out because of the needs of students and this game can help students classify professions based on applied science clusters in Indonesia in accordance with the Republic of Indonesia Constitution Number 12 in 2012 concerning Higher Education and to learn about professions more easily and interactively.

The law No. 12 of 2012 greatly assists school counselors or teacher counseling and counseling to help students recognize and categorize future references. By the determining the concepts based on applied science and career development of high school elementary students can be implemented through the use of technology. It is because technology recently eases the students to consider a variety of profession as a reference for their future career. Si-Onet profession game is developed in this study, which is in accordance with the law No. 12 of 2012 in order to know a variety of professions for future career. The development of this game use an android application. Here are the steps of designing "Si-Onet Game Profession":

The first stage is writing an initial draft of the media that includes media design, and guidance on the use of the "Professional Si-Onet Game" application. The material description included in this "Professional Si-Onet Game" application includes several professions in the cluster of applied science.

This application has several features, including information, hints, shuffle, and images of various professions in accordance with Law No. 12 of 2012. In the feature of information, students can see the duration, the players, the advantages, and the steps how to play this game. The, the students are clued that there is a card can be used once only to help the players when they have troubles in matching and finding the pictures, that is by asking for help from the other player. When there are no 
pictures can be matched, players can use 'shuffle'. After finished in matching the pictures of profession, questions about a chance for help popped up, all the players have to discuss it with guidance from counselor.

This research is still in the early stages of design and concept, so what we are doing now is developing and strengthening the concept of Law No. 12 of 2012 as the basis for making applications. Based on the results above, researchers will continue to develop applications that will help students in reference to their ideals. With a touch of technology, it is expected that this application can help reference the ideals of students and learn to recognize the variety of professions more easily and interactively, because in this application using animated images that make students interested in using and expected students motivated to like the profession that has become a dream front.

This study is still in initial stage of design and concept; hence what we are doing is developing an application in accordance with the law No. 12 of 2012 as the basis to enhance the project. The researcher will continue to develop this application in order to help students to have reference for their ideals. By the implementation of technology, it is expected that the students will easily know and consider about a variety of profession interactively since this application use animation picture that absolutely attracts students to be motivated and have a clue for their future career.

\section{CONCLUSION}

The familiarization of career variety is very important for children since it affects to how students will determine their career in the future hence it stand as the reference for them. Students definitely have a right to choose their own future career based on their needs and interests. Counseling teachers become one of the alternatives in giving information related to the familiarization of career variety for students' future. In this study, a variety of profession is adopted from cluster of applied science that expected may help students in determining their future career.

Si-Onet Game Profession itself is expected to assist both students and counseling teachers to know that there are a lot of professions based on the cluster of applied science in attractive way. For further research, hopefully there is an application that can be applied to a large amount of society. Absolutely, the time consumed, the sources of material, and the design should be taken into account. Hence, for further researcher it is expected that the application is tested by experts and mass trials. By the trials, it will determine how effective the application is.

\section{REFERENCES}

Adriana, D. (2011). Tumbuh Kembang \& Terapi Bermain pada Anak. Jakarta: Salemba Medika.

Adriansyah, Sumarno. (2012). Aplikasi Media Pembelajaran Paud Untuk Pengenalan Profesi
Berbasis Android. Jurnal Informatika. Universitas Muhammadiyah Sidoarjo.

Azhari. (2016). Pengembangan Media Komik Sebagai Sarana Pengenalan Karir SiswaKelas IV SDN 1 Babatan Surabaya. Jurnal Unesa.

Beck, A. (2016). Using The Board Game "The Last Straw: A Board Game The Social Determinants of Health" as an Engaged Pedagogical Method in The Sociology Classroom. Illinois: Proquest LLC.

Brown, Duane \& Associates. (2002). Career Choice and Development Fourth Edition. San Fransisco: Wiley \& Sons, Inc.

Hartung, P.J., Porfeli, E.J., \& Vondracek, F.W. (2005). Child Vocational Development: A Review and Reconsideration. Journal of Vocational Behavior. 66 (2005), 385-419

Organisation for Economic Co-opeartion and Development. (2004). Career Guidance: A Handbook for Policy Makers. Paris: OECD.

Rina, Baroto. (2016). Perancangan Aplikasi Mobile Pengenalan Ragam Profesi Sebagai Referensi Cita-cita Untuk Anak Usia 10-12 Tahun, Seri Kesehatan Profesi Dokter Hewan dan Ahli Gizi. Jurnal Teknik ITS. Vol. 5., No.2.

Rossiter, John R, Larry Percy. (1998). Advertising Comunication and Promotion Management, Edisi kedua, Singapura: McGraw-Hill.

Salahudin, A. (2010). Bimbingan dan Konseling.Bandung: CV Pustaka Setia.

Sunaryo Kartadinata \& Nani Sugandi. (2002). Bimbingan dan Konseling di Sekolah Dasar. Bandung: CV Maulana.

Super, D.E. (1990). A life-Span, life-Space Approach. Career Choice and Development. In Brown, D. \& Brooks, L. San Fransisco: Jossey-Bass Publisher.

Undang-undang Republik Indonesia Nomor 12 Tahun 2012 Tentang Pendidikan Tinggi.

Zunker, Vernon G. (2006). Career Counseling: A Holistic Approach Seventh Edition. USA: Thompson Brooks/Cole. 